\title{
Satisfaction and Motivation as Determinants of Teacher Performance
}

\author{
Rasto', Siti Yulianti Maulani2 $^{2}$ \\ Universitas Pendidikan Indonesia \\ Email : rasto@upi.edu
}

\begin{abstract}
The goal of this research is to investigate the influence of satisfaction and motivation of teacher performance. The method of this research is explanatory survey. Data were collected by questionnaire rating scale 5 scale models. Respondent are teachers of state Vocational High School. Respondent are teachers of State Vocational High School in Cimahi. Data analysis technique using regression. The finding of this research indicated that satisfaction and motivation have a positive and significant influence on teacher performance, either partially or simultaneously. The research concluded that the teacher's performance can be improved by improving the satisfaction and motivation.
\end{abstract}

\section{Keywords: satisfaction, motivation, teacher performance, vocational high school}

Education is essentially one of the basic human needs in order to improve the quality of human resources in order to achieve an increasingly advanced and prosperous level of life (Susanto, 2012). Education has very valuable and significant contribution in improving the quality of a nation (Muhardi, 2004). It is impossible to accelerate the progress of the nation in the future without being supported by progress in the field of education (Muhardi, 2004).

The world of education must strive to continually pursue and adjust the competencies expected by the world of work that is full of changes and uncertainties because of the difficulties to predicted (Utaminingsih, 2011). Vocational High School (SMK) is a formal education subsystem that is organized to prepare middle-level skilled labor. Learning in Vocational Schools must be relevant to current and future workforce needs (Fitrihana, 2017). As an educational institution, vocational schools, educating prospective workers, must prioritize the development of an educationoriented system on increasing graduates who have character in accordance with the needs of the business/industry (Hariyono, 2016). The pattern of education in Vocational Schools must guarantee three domains (attitudes, knowledge, and skills) that are integrated in the best education patterns, so that graduates are appropriate with the needs of the business/industry (link and mach) (Bakar, 2018; Munastiwi, 2015). The quality orientation of SMK graduates who have been oriented to hard skills has changed with the inclusion of soft skill development elements that are very important and needed in career development in the business world and industry (Utaminingsih, 2011). Vocational graduates who are prepared to enter the workforce require knowledge preparation that is formed through a professional teacher.

Teachers are important element in the education system to create quality human resources. The other components, such as curriculum, infrastructure, costs, etc. don't have important meaning if it is not accompanied by adequate teacher quality (Mafudah 
and Asrori, 2016). Teacher's profession is a support profession for many parties to overcome the social changes that goes on so fast and rapidly (Setiawan and Sitorus, 2017). Without the influence of teacher corps, the renewal policy doesn't have any meaning (Sobandi, 2010).

The interesting aspects studied from teacher is the aspect of performance, because teacher performance is the most important input in education (Koswara and Rasto 2016). Effective and efficient teacher performance will result in qualified human resources that is graduates who are efficient and effective in accordance with their intended goals (Sukma and Sutarni, 2018). Professionalism can be created through good performance. Teacher performance is very important in realizing national education goals and determining the high and low quality of education (Susanto, 2012). Teacher performance or work performance must always be improved to solve the challenges in education world to produce high quality human resources that enable to compete in global era (Alfons, 2018).

High performance will make employees more loyal to the organization, more motivated to work, work with pleasure and the more important is increasing the achievement of high productivity and performance (Harris and Sass, 2014). Low performance causes ineffectiveness work. Low performance will cause problems for the organization, which is unexpected work. Low performance will impact on poor productivity and finally impede to achieve the organization goals.

But in reality, teacher performance is not optimal. Empirical facts show that teachers in each province in Indonesia are mostly in the less category. Statistical data from the Ministry of Education and Culture (Kemendikbud) which contains an analysis of education data at the primary and secondary education level shows that nationally the performance of primary and secondary education teachers is $76.43 \%$ in the less category. The biggest performance of primary and secondary education teachers was occupied by Bali Province, which amounted to $81.20 \%$, included in the pratama category while the performance of elementary and junior secondary school teachers was occupied by East Nusa Tenggara at $71.84 \%$, including in the less category. The data also shows that 30 provinces included in the less category and only 4 provinces included in the pre-primary category, that were Bangka Belitung, South Kalimantan, Central Kalimantan and Bali.

Since the importance of teacher performance in education, efforts are needed to improve teacher performance. Based on behavioral theory, satisfaction and motivation factors are factors that strongly influence teacher performance (Robbins and Judge, 2015). Based on these things the formulation of the problem from this study is "is there any influence of satisfaction and motivation on teacher performance? "Thus the goals of this study was to analyze the effect of satisfaction and motivation on teacher performance.

One of the important elements in creating qualified human resources is the creation of job satisfaction for every employee. Job satisfaction created in an organization shows that the organization has filled the needs of the most important necessity of its organizational activities.

Job satisfaction is a psychological atmosphere about pleasant or unpleasant feelings to their work (Ruvendi, 2015). Job satisfaction is an emotional state experienced by the teacher correlated to the duties and obligations as educators in the school (Farooqui and Nagendra, 2014; García Torres, 2019; Shoshani and Eldor, 2016). 
High job satisfaction makes employees more loyal to companies or organizations (Azhar and Rasto, 2018), encourages morale, discipline, and work performance (Hasibuan, 2008), can work well, full of enthusiasm, active and can perform better than employees who do not get job satisfaction (Sutrisno, 2009).

(Farooqui and Nagendra, 2014; García Torres, 2019) stated that companies need to pay attention to the job satisfaction of their employees. The first reason is employee value. The Second is the reason for mental health. The third are physical health reasons (Suntari and Rasto, 2018).

Mathis (2001) argues that motivation is a desire to someone that causes person to take action and achieve the goal (Sofarudin and Djastuti, 2014). Motivation is formed by the attitude (attitude) of an employee when faced the work situations (Darmawan and Mukzam, 2013). Motivation is a driving force or attraction that caused behavior into a particular goal (Mulyasa, 2003).

Teachers who have strong achievement motivation will have a passion, desire, and great energy in themselves to work optimally as possible (Syamsiah and Yuniarsih, 2018). High work motivation raises an attitude to do things well as possible, desires to be a person who is advanced and has mastered certain fields, doing things that are difficult with satisfying results, doing something that is very meaningful, doing something better than others (Mangkunegara, 2002), has a work enthusiasm, is willing to work together, work effectively and integrated (Purba, 2016) has a level of responsibility, dares to take and bear risks (Bateman and Snell, 2002). Someone with low motivation results in a lack of efficiency in work and cannot achieve the expected work productivity.

Teacher's performance is a description of the results carried out by educators related to their tasks and their responsibility (Uno and Lamatenggo, 2013). Teacher's performance is behavior or response that refers to what they do faced their job (Sass et al., 2014). Performance is an achievement of certain jobs which directly reflected in the output produced (Siagian, 2002). It can be concluded that teacher performance is the result of work that is closely related to the implementation of tasks as professional teachers (Anggraeni and Rasto, 2016).

Teacher performance is a framework done by educators related to their duties including teaching, working on school administration and learning administration, carrying out guidance and services to students, and carrying out assessments (Sukma and Sutarni, 2018). Teacher performance is a process of carrying out learning both in the classroom and outside the classroom in addition to working on other activities, such as working on school administration and learning administration, and implementing guidance and services for students and carrying out assessments (Sarifani and Rasto, 2017). Teacher's performance includes teaching activities, working on school administration and learning administration, implementing guidance and services for students, and carrying out assessments (Sukma and Sutarni, 2018).

High performance will make employees more loyal to the organization, more motivated to work, work with pleasure and the more important is increasing the posibility of achieving high productivity and performance (Harris and Sass, 2014; Pope, 2019; Sass et al., 2014). Low performance will cause a problem for the organization, because the performance produced by the employee is not as expected. Low performance will have an impact on poor productivity and will ultimately hinder the achievement of organizational goals. 
Teacher performance is influenced by many factors. Factors that influence performance include learning, motivation, personality, emotion, perception, training, leadership effectiveness, job satisfaction, individual decision making, performance appraisal, attitude measurement, employee selection, work design and work stress (Robbins and Judge, 2015).

Based on literature review as described above, the theoretical framework can be described as shown in Figure 1 below.

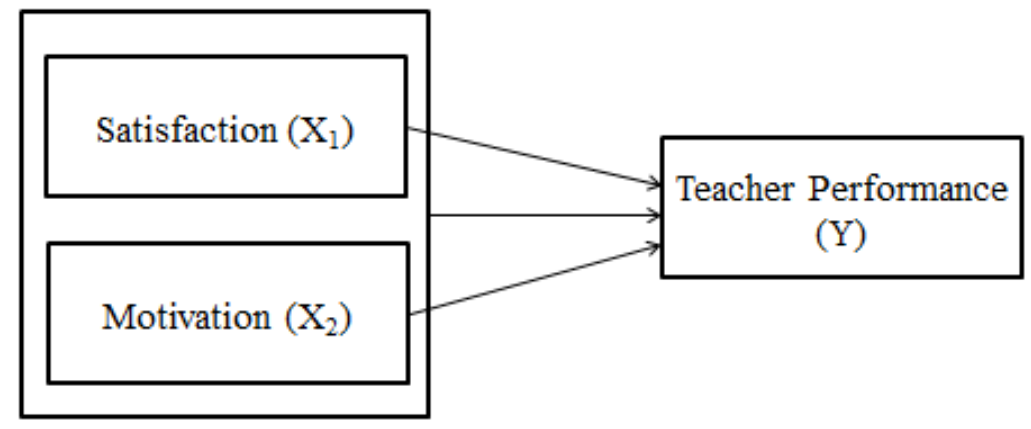

Figure 1 Theoretical Framework

Based on the theoretical framework, this study has the following hypothesis:

$\mathrm{H}_{1}$ : There is an influence between satisfaction on teacher performance

$\mathrm{H}_{2}$ : There is an influence between motivation on teacher performance

$\mathrm{H}_{3}$ : There is an influence between satisfaction and motivation on teacher performance

\section{METHODS}

This research used a survey method. Respondents were teachers in one of the Vocational High Schools (SMK) in Cimahi City, West Java. The instrument for data collection is a rating scale model questionnaire consisting of three parts. The first part consists of 16 item of questions which are questionnaires to measure respondent's perceptions of satisfaction outlined from five indicators namely enjoying their work, loving their work, work morale, discipline and work performance. The second part consists of 14 items which are questionnaires to measure respondents' perceptions of motivation outlined from six indicators, namely enthusiasm for work, active in doing work, optimism for work, confidence, curiosity and never giving up. The third part consists of 12 item of questions which are questionnaires to measure respondents' perceptions of teacher performance outlined in 5 indicators namely quality of work, timeliness, initiative, ability and communication.

Descriptive statistics with the average score is used to obtain an overview of the respondent's perceptions of teacher satisfaction, motivation and performance. Inferential statistics that used regression analysis is used to test hypotheses.

\section{FINDINGS AND DISCUSSION Findings}

Job satisfaction in this research was measured through five indicators. The First is enjoy his/her job. People aware of the direction in which he leads, why he goes that way, and how he must go to his goal. He likes his job because he can do it well. The Second is love his job. Giving the best efforts, devotes all forms of attention with 
pleasure to achieve the best goal for his job. Employees want to sacrifice themselves even though it is difficult, even though they are sick, with no time, wherever employees are, they always thinking about their work. The third is work morale. It showed by an inner agreement that arises from a person or group of people to achieve a certain goal in accordance with the set quality standards. Fourth is discipline. Conditions that are created and formed through the process of a series of behaviors that show the values that they believe, obedience, loyalty, order. Fifth is work performance. The work that achieved by someone in carrying out the tasks assigned to him is based on skill and sincerity as well as time (Hasibuan, 2008).

Teacher satisfaction based on respondent's perceptions is in the low category, as indicated by the respondent's average score of 2.56. Table 1 shows the average score of each indicator that measures teacher satisfaction.

Table 1 Description of Teacher's Motivation

Descriptive Statistics

\begin{tabular}{lcccc}
\hline & N & Sum & Mean & Std. Deviation \\
\hline Enjoying their work & 50 & 152 & 3.04 & .835 \\
Loving their work & 50 & 154 & 3.08 & .699 \\
Work morale & 50 & 150 & 2.99 & .739 \\
Discipline & 50 & 147 & 2.94 & .940 \\
Work performance & 50 & 145 & 2.89 & .872 \\
Average & 50 & 128 & 2.56 & .884 \\
Valid N (listwise) & 50 & & & \\
\hline
\end{tabular}

The highest score is in the loving their work indicator which has an average value of 3.08 and is in the medium category. This result shows that the teacher can prioritize the time to work, sacrifice himself and complete the work in sequence. The indicator of work performance has the lowest average score with an average score of 2.89 and is in the medium category. This result implies that the teacher in work performance is not optimal. The teacher is not yet willing to fulfill work targets, initiatives to work, obey work instructions and develop his career.

Work motivation in this research is measured through 6 indicators. These indicators are enthusiastic for work, active in doing work, optimistic for work, confident, curiosity, abstinence when there are mistakes in work, want to trace the cause (Hasibuan, 2007)

Teacher motivation based on respondent's perceptions is in the medium category, as indicated by the respondent's average score of 3.12. Table 2 presents the average score of each indicator that used as a measure of teacher motivation. 
Table 2 Description of Teacher's Motivation

Descriptive Statistics

\begin{tabular}{lcccc}
\hline & N & Sum & Mean & Std. Deviation \\
\hline Enthusiasm for work & 50 & 161 & 3.22 & .686 \\
Active in doing work & 50 & 161 & 3.21 & .663 \\
Optimism for work & 50 & 164 & 3.27 & .656 \\
Confidence & 50 & 160 & 3.19 & .677 \\
Curiosity & 50 & 162 & 3.23 & .666 \\
Never giving up & 50 & 162 & 3.23 & .672 \\
Average & 50 & 156 & 3.12 & .689 \\
Valid N (listwise) & 50 & & & \\
\hline
\end{tabular}

The highest score is in the optimism form work indicator which has an average value of 3.27 an in the medium category. These results indicate that the teacher is willing to think positively in doing work and can control himself in all situations. Indicator of active in doing work has the lowest average score with the average value of 3.21 and in the medium category. This result implied that the teacher's active in doing work is not optimal. The teacher has not been able to maximize the time in completing the task and the teacher has not been able to carry out the task immediately.

Teacher's performance in this research was measured through 5 indicators. The first is the quality of work that consists of the results of work obtained, the suitability of work results with organizational goals and the benefits of work. The second is the timeliness that consists of structuring the plan/activity of the work, the accuracy of the work plan with the results of work and the timeliness in completing the task. The third is the initiative that consists of giving ideas to organization and the actions taken to resolve the problems faced. Fourth is ability that consists of abilities possessed, skills possessed, and the ability to utilize resources or potential. Fifth is communication that consists of internal organization communication, external communication of the organization, and relations and cooperation in the implementation of tasks (Uno and Lamatenggo, 2013).

Teacher performance based on respondent's perceptions is in the low category, as indicated by the respondent's average score of 2.56. Table 3 presents the average score of each indicator that used as a measure of teacher performance.

Table 3 Description of Teacher's Performance

\section{Descriptive Statistics}

\begin{tabular}{lcccc}
\hline & N & Sum & Mean & Std. Deviation \\
\hline Quality of work & 50 & 137 & 2.74 & 1.006 \\
Timeliness & 50 & 137 & 2.73 & .952 \\
Initiative & 50 & 139 & 2.77 & .938 \\
Ability & 50 & 140 & 2.79 & .948 \\
Communicaion & 50 & 146 & 2.91 & .907 \\
Average & 50 & 128 & 2.56 & 1.003 \\
Valid N (listwise) & 50 & & & \\
\hline
\end{tabular}


The highest score is in the communication indicator which has an average value of 2.91 and in the medium category. These results indicate that work information has been received and delivered appropriately and has collaborated in work. Indicators of timeliness have the lowest average score with an average score of 2.73 and in the medium category. This result implies that the teacher's timeliness in his work is not optimal. The teacher has not made a work plan before doing the work, the work plan that has not been made in accordance with work and work has not been done in a timely manner.

Linear regression equation which shows the effect of satisfaction on teacher performance is $\widehat{Y}=\alpha+b=3.220+0.681(\mathrm{X})$. Positive sign $(+)$ shows the relationship between independent variables with dependent variables running one direction, which means that every increase or decrease in one level of the variable, will be followed by an increase or decrease in one other variable, so that the higher of satisfaction, the higher the teacher's performance is, vice versa.

Hypothesis testing shows that $t_{\text {count }}>t_{\text {table }}$ with a value of $8.483>2.0117$. This shows that there is a positive and significant influence between satisfactions with teacher performance. Based on the calculation of the coefficient of determination, the amount of satisfaction with teacher performance is equal to 0.600 or $60.0 \%$.

This result is suitable with some expert opinions that state the link between satisfaction and performance. There is a relationship between job satisfaction and performance (Luthans, 1995). Teacher satisfaction and dissatisfaction affect their performance. In this case, identifying the level of teacher job satisfaction is important (Demirtas, 2010).

Job satisfaction will arise if employees have feelings of pleasure in enjoying their role as workers. The more satisfied employees feel with their work, the greater the assessment of the work. Conversely, the more dissatisfied employees feel with their work, the smaller the assessment of their work.

Job satisfaction results in an optimal work productivity. Productivity is a result of performance. Achievement of teacher job satisfaction is very important to note because satisfied teachers will provide good work results, especially for the implementation of the learning process. Every school needs to pay attention to teacher job satisfaction because it is related to achieving the objectives of quality and quality of education.

Linear regression equation which shows the effect of motivation on teacher performance is $\widehat{Y}=\alpha+b=4.686+0.766(X)$. Positive sign ( + ) shows the relationship between independent variables with dependent variables running one direction, which means that every increase or decrease in one level of the variable, will be followed by an increase or decrease in one other variable, so that the higher of the motivation, the higher teacher's performance vice versa.

Hypothesis testing shows that the value of $t_{\text {count }}>t_{\text {table }}$ with a value of $8.541>$ 2.0117. This shows there is a positive and significant influence between motivations on teacher performance. Based on the calculation of the coefficient of determination, the amount of motivation on teacher performance is 0.603 or $60.3 \%$.

This result is relevant with some expert opinions that state the relationship between motivation and performance. The level of performance achieved is determined by three interrelated factors, such as ability, motivation, and resources (Lussier, 2008). Low motivation can cause a person's performance is not optimal. 
Motivation is a desire in a person that causes the person to take an action (Mathis and Jackson, 2006).

The work motivation shown by a teacher that raises the achievement of optimal work targets. A teacher who has work motivation is characterized by the emergence of an attitude of enthusiasm, the desire to move forward, and achieve effective work results. Schools need to pay attention to the teacher's work motivation, because the success of the work is greatly influenced by the compatibility between job requirements and the motivation brought by the teacher concerned. So motivation is an important factor in encouraging optimal work results

The linear regression equation that shows the effect of satisfaction and motivation on teacher performance is $\widehat{Y}=\alpha+b=0.761+0.360\left(\mathrm{X}_{1}\right)+0.418\left(\mathrm{X}_{2}\right)$. Positive sign (+) shows the relationship between independent variables and dependent variables running in one direction, which means that every increase or decrease in one level of the variable, will be followed by an increase or decrease in one other variable, so that the higher satisfaction and motivation, the higher teacher performance and vice versa.

Hypothesis testing shows that the value of $f_{\text {count }}>f_{\text {table }}$ value is $43.003>2.81$. This implied that there is a positive and significant influence between satisfaction and motivation on teacher performance. Based on the calculation of the coefficient of determination, the amount of satisfaction and motivation for teacher performance is 0.647 or $64.7 \%$.

\section{Discussion}

These results are relevant with the results of several studies which led to the conclusion of the influence of satisfaction and motivation on teacher performance (Bentea and Anghelache, 2012; Farooqui and Nagendra, 2014; Shoshani and Eldor, 2016).This result is also suitable with some expert opinions stating the link between satisfaction and performance. Factors that influence performance include learning, motivation, personality, emotion, perception, training, leadership effectiveness, job satisfaction, individual decision making, performance appraisal, attitude measurement, employee selection, work design and work stress (Robbins and Judge, 2015).

Both of satisfaction and motivation influence the performance produced. The existence of satisfaction but not balanced with motivation, will lead to less optimal work results because there is no encouragement in themselves to work well. Conversely a teacher or worker who experiences dissatisfaction but has motivation will not produce good performance because there is no positive feeling in him in achieving work goals. Therefore satisfaction and motivation must go in appropriate way each other because both of them influence in creating quality performance.

\section{CONCLUSION}

Teacher performance is one of the important aspects in improving the quality of learning services in vocational high schools. The quality of work, the accuracy of work, initiative in work, ability to work, and communication are five aspects that can generally be measured as teacher performance measurement. Satisfaction and motivation are two factors that have been empirically proven to influence teacher 
performance. Therefore teacher performance can be increased through efforts in order to increase teacher satisfaction and motivation.

\section{REFERENCES}

Alfons, M., 2018. The Influence of Work Environment, Work Motivation and Job Satisfaction on Teacher Performance of State Middle Schools in West Dolo District, Sigi Regency, Central Sulawesi Province.. Katalogis, 6(5), 47-56. (Indonesian Origin)

Anggraeni, R., \& Rasto., 2018. Job Satisfaction and Organizational Commitment as Determinants of Teacher Performance. (Indonesian Origin)

Azhar, M. N., \& Rasto., 2018. Work Environment and Implications for Employee Job Satisfaction. Jurnal Pendidikan Manajemen Perkantoran, 2(1), 128-131. (Indonesian Origin)

Bakar, R., 2018. The influence of professional teachers on Padang vocational school students' achievement. Kasetsart Journal of Social Sciences 39, 67-72. https://doi.org/10.1016/j.kjss.2017.12.017

Bateman, T. S., \& Scott A. S., 2002. Manajement (Competing in The New Era), 5ed., New York:McGraw Hill

Bentea, C., Anghelache, V., 2012. Teachers' motivation and satisfaction for professional activity. Procedia - Social and Behavioral Sciences, PSIWORLD 2011 33, 563-567. https://doi.org/10.1016/j.sbspro.2012.01.184

Darmawan, A. S., Hamid, D., Mukzam, M. D., 2013. Effect of Work Motivation and Work Ability on Employee Performance (Study on Employees of PT. PLN (Persero) Distribution of East Java Service and Network Area (APJ) Malang). Administrasi Bisnis Student Journal, 1-9. (Indonesian Origin)

Demirtas, Z., 2010. Teachers' job satisfaction levels. Elsevier, 1069-1073.

Farooqui, Ms.S., Nagendra, A., 2014. The Impact of Person Organization Fit on Job Satisfaction and Performance of the Employees. Procedia Economics and Finance, Shaping the Future of Business and Society 11, 122-129. https://doi.org/10.1016/S2212-5671(14)00182-8

Fitrihana, N., 2017 The Canvas Business Model for Developing Teaching Factory in Fashion Vocational Schools to Support the Growth of Creative Industries.. Jurnal Taman Vokasi, 5(2), 212-218. (Indonesian Origin)

García Torres, D., 2019. Distributed leadership, professional collaboration, and teachers' job satisfaction in U.S. schools. Teaching and Teacher Education 79, 111-123. https://doi.org/10.1016/j.tate.2018.12.001

Hariyono, H., 2016. The Importance of Character Education for Vocational Students as an Effort to Improve Education Quality. Jurnal Pendidikan Dasar dan Menengah (JUPEDASMEN), 2(1). (Indonesian Origin)

Harris, D.N., Sass, T.R., 2014. Skills, productivity and the evaluation of teacher performance. Economics of Education Review 40, 183-204. https://doi.org/10.1016/j.econedurev.2014.03.002

Koswara, K., \& Rasto, R., 2016. Teacher Competence and Performance Based on Professional Certification. Jurnal Pendidikan Manajemen Perkantoran, 1(1), 6474. (Indonesian Origin)

Lussier, R. N., 2008. Human Relation in Organization Application and Skill Building. New York: Pfeiffer.

Luthans, F., 1995. Organizational Behavior. Tokyo: Mc Graw-hill Kogakhusa. Ltd. 
Mafudah, L., \& Asrori., 2016. The Effect of Curriculum Understanding, Work Motivation, and Principal Leadership on Vocational Teacher Performance. Economic Education Analysis Journal, 5(2), 389-401. (Indonesian Origin)

Mangkunegara, A. P., 2002. Manajemen Sumber Daya Manusia.

Mathis, R.L., \& J.H. Jackson., 2006. Human Resource Management: Manajemen Sumber Daya Manusia. Terjemahan Dian Angelia. Jakarta: Salemba Empat.

Muhardi, M., 2004. Contribution of Education in Improving the Quality of the Indonesian Nation. Mimbar: Jurnal Sosial dan Pembangunan, 20(4), 478-492. (Indonesian Origin)

Mulyasa, E., 2003 Competency Based Curriculum. Bandung: Remaja Rosdakarya. (Indonesian Origin)

Munastiwi, E., 2015. The Management Model of Vocational Education Quality Assurance Using 'Holistic Skills Education (Holsked).' Procedia - Social and Behavioral Sciences, The 4th World Congress on Technical Vocational Education and Training (4thWoCTVET), 5-6 December 2014, Universiti Tun Hussein Onn Malaysia, MALAYSIA 204, 218-230. https://doi.org/10.1016/j.sbspro.2015.08.144

Pope, N.G., 2019. The effect of teacher ratings on teacher performance. Journal of Public Economics 172, 84-110. https://doi.org/10.1016/j.jpubeco.2019.01.001

Purba, J. H., 2016. Motivation and Communication Analysis of Employee Performance at the Center for Development and Empowerment of Educators and Education Personnel (P4TK) Medan. Jurnal Ilmiah Methonomi, 2(1), 34-47. (Indonesian Origin)

Robbins, S. P., \& Judge, T. A., 2015. Organisation Behaviour. Jakarta: Salemba Empat.

Ruvendi, R., 2015 The Influence And Leadership Style Of Its Influence On Employee Job Satisfaction At The Bogor Center for Agricultural Product Industry.. Jurnal Ilmiah Binaniaga, 01(01), 17-26. (Indonesian Origin)

Sarifani, K. A. K., \& Rasto, R., 2017. Keterampilan Manajerial Kepala Sekolah dan Budaya Mutu sebagai Determinan Kinerja. Jurnal Pendidikan Manajemen Perkantoran, 1(1), 30-40. (Indonesian Origin)

Setiawan, D., \& Sitorus, J., 2017. Urgensi Tuntutan Profesionalisme dan Harapan Menjadi Guru Berkarakter (Studi Kasus : Sekolah Dasar dan Sekolah Menengah Pertama di Kabupaten Batubara). Cakrawala Pendidikan, (1), 122-129. (Indonesian Origin)

Sass, T.R., Semykina, A., Harris, D.N., 2014. Value-added models and the measurement of teacher productivity. Economics of Education Review 38, 9-23. https://doi.org/10.1016/j.econedurev.2013.10.003

Shoshani, A., Eldor, L., 2016. The informal learning of teachers: Learning climate, job satisfaction and teachers' and students' motivation and well-being. International Journal of Educational Research 79, 52-63. https://doi.org/10.1016/j.ijer.2016.06.007

Siagian, S. P., 2002 Tips for Increasing Work Productivity. Jakarta: Rineka Cipta. (Indonesian Origin)

Sobandi, A., 2010 The Influence of Teacher Competence on Teaching Performance of Vocational High School Business and Management Expertise in Bandung City.. manajerial, 9(17), 25-34. (Indonesian Origin)

Sofarudin, A., \& Djastuti, I., 2014. Capturing the Motivation of Heroes of Education (Study on Non-Permanent Teachers of Madrasah Aliyah in Pekalongan City). Diponegoro Journal of Management, 1-13. (Indonesian Origin) 
Sukma, F. M., \& Sutarni, N., 2018. Effect of ISO 9001: 2008 Based Resource Management on Teacher Performance. Jurnal Pendidikan Manajemen Perkantoran, 103-110. (Indonesian Origin)

Suntari, R., \& Rasto., 2018. The Role of Job Satisfaction in Improving Employee Performance. Jurnal Pendidikan Manajemen Perkantoran, 1(2), 86-91. (Indonesian Origin)

Sutrisno, E., 2009. Human Resources Management. Jakarta: Kencana. (Indonesian Origin)

Uno, H. B., \& Lamatenggo., 2013 Theory of Performance and Measurement.. Jakarta: Bumi Aksara. (Indonesian Origin)

Utaminingsih, S., 2016 Career-Based Soft Skill Development at Vocational Schools in Semarang City.., 6(2), 119-133. (Indonesian Origin) 